Al Maal : Journal of Islamic Economics and Banking

http://jurnal.umt.ac.id/index.php/jieb

E-ISSN : $\quad 2580-3816$

Vol : 1 No 1 Bulan Juli Tahun 2019

Hlm : $83-93$

DOI : 10.31000/almaal.v1i1.1817

\title{
Optimalisasi Peluang Dan Tantangan Ekonomi Islam Dalam Menghadapi Masyarakat Ekonomi Asean
}

\section{Zainal Arif ${ }^{1, *}$}

${ }^{1}$ Prodi Perbankan Syariah, Universitas Muhammadiyah Tangerang, Tangerang, Indonesia

*Email: zarifpambon@gmail.com

\section{ABSTRACT}

The ASEAN leader have agreed to conduct coorperation in the field of economics. Called the ASEAN Economic Community or (MEA). The MEA is mutual agreement to integrate a various ASEAN countries (Indonesia, Singapura, Malasyia, Brunai Darussalam, Thailand, Kamboja, Vietnam, Laos and Myanmar). Where the countries has a socio-culture background, politic, economic, ideological interest into ASEAN community. As an integrated ASEAN is expected to cooperate in improving efficiency and spuring the economic competitiveness of ASEAN wich is indicated through the free flow: goods, services, investment, labor and capital. MEA is a challenge for Islamic economy at the same give a opportunities for the future of Islamic economy, Islamic finance. Because the Sharia bussines will evolve across the ASEAN countries.

Keywords: Optimization; Opportunities; Challenges; Islamic Economy; MEA

\begin{abstract}
ABSTRAK
Pemimpin ASEAN telah sepakat untuk melakukan kerjasama di bidang ekonomi. Disebut Masyarakat Ekonomi ASEAN atau (MEA). MEA adalah kesepakatan bersama untuk mengintegrasikan berbagai negara ASEAN (Indonesia, Singapura, Malasyia, Brunai Darussalam, Thailand, Kamboja, Vietnam, Laos dan Myanmar). Di mana negara-negara memiliki latar belakang sosial budaya, politik, ekonomi, bunga ideologi dalam masyarakat ASEAN. Sebagai ASEAN yang terintegrasi diharapkan untuk bekerja sama dalam meningkatkan efisiensi dan spuring daya saing ekonomi ASEAN Wich ditunjukkan melalui aliran bebas: barang, jasa, investasi, tenaga kerja dan modal. MEA merupakan tantangan bagi perekonomian Islam pada saat yang sama memberikan peluang bagi masa depan ekonomi Islam, keuangan Islam. Karena bussines Syariah akan berkembang di negara-negara ASEAN.
\end{abstract}

Kata kunci: Optimalisasi; Peluang; Tantangan; Ekonomi Islam; MEA 


\section{Pendahuluan}

Tepat pada tanggal 1 Januari 2015 yang lalu bangsa-bangsa di kawasan Asia Tenggara atau lebih dikenal dengan ASEAN akan memasuki era baru dalam hubungan integrasi perekonomian dan perdagangan dalam bentuk Masyarakat Ekonomi Asean (MEA). Siap atau tidak siap semua negara di kawasan ASEAN sudah harus meleburkan batas territorial negaranya dalam satu pasar bebas yang diperkirakan akan menjadi tulang punggung perekonomian di kawasan Asia setelah China.

Menghadapi MEA, di satu sisi masyarakat ASEAN seharusnya bergembira. Betapa tidak, MEA diharapkan dapat menciptakan komunitas regional yang diproyeksikan dapat menjaga stabilitas politik dan keamanan regional ASEAN, meningkatkan daya saing kawasan secara keseluruhan di pasar dunia, mendorong pertumbuhan ekonomi kawasan, mengurangi kemiskinan dan meningkatkan standard hidup penduduk negara anggota ASEAN. MEA merupakan sebuah kesepakatan di antara negara-negara ASEAN dalam rangka penguatan di berbagai sektor, terutama sebagai bentuk pertahanan dari goncangan global. Implementasi kebijakan ini mirip dengan Free Trade Area (FTA) yang akan yang dilaksanakan pada tahun 2020 nanti, namun dalam cakupan yang lebih kecil yaitu ASEAN. Kebijakan ini telah direncanakan jauh hari sebelumnya, namun karena kebutuhan yang mendesak khususnya dalam hal kerja sama bilateral dan penguatan negara-negara ASEAN dari serangan produk luar negeri maka diajukanlah implementasi MEA paling lambat tahun 2015.

Dalam integrasi MEA, terdapat empat hal yang akan menjadi fokus MEA pada tahun 2015 yang dapat dijadikan sebagai momentum yang baik bagi bagsa-bangsa di ASEAN. Pertama, negara-negara di kawasan ASEAN ini akan dijadikan sebagai sebuah wilayah kesatuan pasar dan basis produksi; Kedua, MEA akan dibentuk sebagai kawasan ekonomi dengan tingkat kompetisi yang tinggi, yang memerlukan suatu kebijakan yang meliputi competition policy, consumer protection, Intellectual Property Rights (IPR), taxation dan e-commerce; Ketiga, MEA pun akan dijadikan sebagai kawasan yang memiliki perkembangan ekonomi yang merata, dengan memprioritaskan pada Usaha Kecil Menengah (UKM); Keempat, MEA akan diintegrasikan secara penuh terhadap perekonomian global, dengan membangun sebuah sistem untuk meningkatkan koordinasi terhadap negara-negara anggota.

Sebagai negara dengan penduduk muslim terbesar, sudah selayaknya Indonesia menjadi pelopor dan kiblat pengembangan industri keuangan syariah di dunia. Hal ini bukan merupakan 'impian yang mustahil' karena potensi dan peluang Indonesia untuk menjadi global player keuangan syariah sangat besar khususnya dalam mengahdapi MEA, diantaranya : (i) jumlah penduduk muslim yang besar menjadi potensi nasabah industri keuangan syariah; (ii) prospek ekonomi yang cerah, tercermin dari pertumbuhan ekonomi yang relatif tinggi (kisaran 6,0\%-6,5\%) yang ditopang oleh fundamental ekonomi yang solid; (iii) peningkatan sovereign credit rating Indonesia menjadi investment grade yang akan meningkatkan minat investor untuk berinvestasi di sektor keuangan domestik, termasuk industri keuangan syariah; dan (iv) memiliki sumber daya alam yang melimpah yang dapat dijadikan sebagai underlying transaksi industri keuangan syariah.

Di lingkup internasional, Ekonomi Islam mengalami perkembangan yang sangat pesat. World Islamic Banking Competitiveness melaporkan antara tahun 2011-2012 yang disampaikan pada 18 th Annual The World Islamic Bank Conference 2011 menyatakan 
bahwa ekonomi global dan pasar keuangan berada pada titik balik. Pertumbuhan Ekonomi Islam menunjukkan bahwa aset perbankan syariah secara global, akan mencapai \$ 1,1 triliun pada 2012 (2010: \$ 826 miliar). Sedangkan menurut UK Islamic Finance menyatakan asset global keuangan syariah telah mencapai $\$ 1,130$ pada tahun 2010 dan diperkirakan sebesar \$1,289 triliun pada ta-hun 2011. (Mulawarman, 2013)

Dalam kaitannya dengan Ekonomi Islam dewasa ini, wilayah Asia Tenggara dapat disebut sebagai rumah produksi bagi keahlian dan inovasi (power house of skills and innovation). Asia Tenggara dengan sejumlah negara yang mayoritas penduduknya beragama Islam memang menjadi perhatian internasional dalam perkembangan Ekonomi Islam. (Abu Su'ud, 1968)

Sementara itu perkembangan ekonomi Islam berkembang baik sebagai ilmu pengetahuan maupun sebagai sebuah sistem. Implementasi perkembangan industri perbankan dan keuangan syariah dapat dilihat dari produk yang dihasilkan seperti perbankan syariah, asuransi syariah, pasar modal syariah, reksadana syariah, obligasi syariah, pegadaian syariah, Baitul Mal wat Tamwil (BMT). Demikian pula di sektor riil, seperti Hotel Syariah, Multi Level Marketing Syariah, dsb. Perkembangan aplikasi Ekonomi Islam di Indonesia sendiri dimulai sejak didirikannya Bank Muamalat Indonesia tahun 1992, dengan landasan hukumnya UU Nomor 7 Tahun 1992 tentang perbankan, yang telah direvisi dalam UU nomor 10 tahun 1998. (Yulianti,2013)

Dalam hal mempercepat pertumbuhan ekonomi dimulai dari pembenahan internal kondisi perekonomian disuatu negara bahkan sampai melakukan kerjasama internasional. Ada beberapa faktor yang mempengaruhi pertumbuhan ekonomi yaitu faktor sumber daya manusia, faktor sumber daya alam, faktor ilmu pengetahuan dan teknologi, faktor budaya dan faktor daya modal. Jika melihat bagaimana Indonesia mengelola kelima faktor tersebut, beberapa faktor masih belum dapat dimaksimalkan untuk itu Indonesia dan sembilan negara lainnya membentuk ASEAN Community 2015 dengan tujuan yang baik.

MEA adalah bentuk integrasi ekonomi ASEAN dalam artian adanya system perdagaangan bebas antara Negara-negara ASEAN. Indonesia dan sembilan negara anggota ASEAN lainnya telah menyepakati perjanjian Masyarakat Ekonomi ASEAN (MEA) atau ASEAN Economic Community (AEC).

Melihat pesatnya perkembangan ini, maka penulis tertarik untuk meneliti perkembangan "Peran dan Tantangan Ekonomi Islam dalam Menghadapi Masyarakat Ekonomi ASEAN" Penulis akan merumuskan pembahasan yang akan dibahas yaitu, pertama, bagaimana peran dan tantangan ekonomi Islam dalam menghadapi MEA, kedua, Dampak Masyarakat Ekonomi Asean (MEA) Terhadap Masyarakat ASEAN.

\section{KAJIAN LITERATUR}

Ada beberapa pertanyaan yang penulis ajukan dalam kajian teori. Yaitu perbedaan ekonomi Islam dan Ekonomi Syariah? Ada dua pendapat yang penulis temukan dalam wacana Ekonomi. Pertama, Kalau kita lihat dari kecendurngan penggunaan istilah di atas, maka Indonesia lebih menyukai pemakaian istilah ekonomi syariah. Makanya yang muncul adalah perbankan syariah, asuransi syariah, gadai syariah dsb. Berbeda dengan Indonesia, negara-negara lain agaknya lebih menyukai penggunaan istilah ekonomi Islam, sehingga yang muncul adalah lembaga keuangan Islam (Islamic Finance, Islamic 
Banking, Islam Insurance), dan lain-lain. Dengan demikian, penggunaan istilah ekonomi syariah merupakan istilah Indonesia yang menekankan pada aspek legalalistik (fikih muamalah) dalam lembaga keuangan Islam. di Barat penggunaan istilah ini identik dengan sebutan legal economics (ekonomi legalistik). Kedua, perbedaan penyebutan nama ekonomi syariah dengan ekonomi islam, secara terminologis ekonomi Islam terdiri dari 3 (tiga) pilar. Yakni aqidah syariah, dan akhlak. Sedang syariah hanya salah satu pilar dalam islam. Tapi pada asumsi dasarnya perbedaanya terdapat pada ruang lingkup ekonomi. jika ekonomi syariah hanya sebatas pada pilar syariah dalam islam. Ekonomi islam sudah seharusnya menjadi bagian dari ibadah bagi pelakunya, bertransaksi secara halal dengan menghindari yang haram, dan pada saat yang sama pula tetap berperilaku sebagaimana akhlak islami dalam berekonomi.

Kembali kepada topik judul di atas, penulis akan sedikit mengulas tentang Masyarakat ekonomi ASEAN. MEA adalah bentuk integrasi ekonomi ASEAN dalam artian adanya system perdagaangan bebas antara Negara-negara asean. Indonesia dan sembilan negara anggota ASEAN lainnya telah menyepakati perjanjian Masyarakat Ekonomi ASEAN (MEA). Pada KTT di Kuala Lumpur pada Desember 1997 Para Pemimpin ASEAN memutuskan untuk mengubah ASEAN menjadi kawasan yang stabil, makmur, dan sangat kompetitif dengan perkembangan ekonomi yang adil, dan mengurangi kemiskinan dan kesenjangan sosial-ekonomi.

Pada KTT Bali pada bulan Oktober 2003, para pemimpin ASEAN menyatakan bahwa Masyarakat Ekonomi ASEAN (MEA) akan menjadi tujuan dari integrasi ekonomi regional pada tahun 2020, ASEAN Security Community dan Komunitas Sosial-Budaya ASEAN dua pilar yang tidak terpisahkan dari Komunitas ASEAN. Semua pihak diharapkan untuk bekerja secara yang kuat dalam membangun Komunitas ASEAN (2020).

\section{Hasil dan Pembahasan \\ Perkembangan Ekonomi ASEAN 2015}

Indonesia sudah memasuki era Masyarakat Ekonomi ASEAN 2015, dimana dengan tujuan yang baik itu diharapkan mampu membawa perubahan untuk pertumbuhan ekonomi di Indonesia agar lebih baik. tujuan MEA adalah untuk meningkatkan stabilitas perekonomian antar-Negara ASEAN, artinya meliberalisasikan arus barang, tenaga kerja, investasi dan modal. Liberalisasi arus barang artinya akan terjadi pengurangan dan penghilangan hambatan tarif.

Komponen arus perdagangan bebas barang tersebut meliputi penurunan dan penghapusan tarif secara signifikan maupun penghapusan hambatan non-tarif sesuai skema AFTA. Disamping itu, perlu dilakukan peningkatan fasilitas perdagangan yang diharapkan dapat memperlancar arus perdagangan ASEAN seperti prosedur kepabeanan, melalui pembentukan dan penerapan ASEAN Single Window (ASW) yaitu sistem elektronik kepabeaan, serta mengevaluasi skema Common Effective Preferential Tariff (CEPT) Rules of Origin (ROO) atau surat ketentuan asal barang, maupun melakukan harmonisasi standar dan kesesuaian (standard and conformance). (Winantyo, 2008)

Liberalisasi modal akan dilakukan dengan meniadakan aturan administrasi yang menghambat penanaman modal, artinya semua orang yang masuk kawasan ASEAN dapat menanamkan. modalnya dinegara ASEAN secara lebih mudah. Selain itu adanya 
liberalisasi tenaga kerja dimana kita bebas mencari lapangan pekerjaan tidak hanya di dalam negeri melainkan dikawasan ASEAN.

Dengan demikian, (Pitsuwan, 2009)kemajuan ASEAN bukan lagi didominasi oleh kalangan pejabat pemerintah dan diplomat. Hal ini dikemukakan oleh sekertaris jendral ASEAN Surin Pitsuwan "sejak awal disadari bahwa ASEAN tidak hanya untuk pemerintah jika ingin ASEAN sukses dan maju dan langgeng ASEAN juga melibatkan kalangan bisnis, swasta, media massa, lembaga non-pemerintahan, dan tentunya kalangan masyarakat ASEAN"(LEMHANAS, 2012) Bukan hanya pada perekonomian, perkembangan ini merambah pada tataran enam progam ASEAN social-culture blueprint (ASCCB) yakni: a. Human Development; b. Social welfare and protection; c. Human Right and Justice; d. Ensuring Environmental Sustainability; e. Bulding ASEAN identity; f. Narrowing the Development Gap.

\section{Langkah Strategis Dalam Menghadapi Masyarakat Ekonomi Asean (MEA)}

Pelaksanaan kesepakatan Masyarakat Ekonomi ASEAN (MEA) 2015 sudah berlangsung dua tahun. Indonesia mempersiapkan diri jika tidak ingin menjadi sasaran masuknya produk-produk negara anggota ASEAN. Indonesia harus banyak belajar dari pengalaman pelaksanaan free trade agreement (FTA) dengan China, akibatnya China menguasai pasar komoditi Indonesia. Tidak ada pilihan lain selain menghadapi dengan percaya diri bahwa bangsa Indonesia mampu dan menjadi lebih baik perekonomiannya dalam keikutsertaan Masyarakat Ekonomi ASEAN 2015 ini.

Beberapa langkah strategis yang perlu dilaksanakan oleh pemerintah ialah dari sektor usaha perlu meningkatkan perlindungan terhadap konsumen, memberikan bantuan modal bagi pelaku usaha mikro, kecil dan menengah, memperbaiki kualitas produk dalam negeri dan memberikan label SNI bagi produk dalam negeri agar memiliki nilai ekspor sehingga mampu bersaing, mendorong swasta untuk memanfaatkan pasar terbuka. Dalam sektor investasi, Indonesia dinilai akan menjadi negara yang lebih banyak diuntungkan karena diharapkan investasi asing mampu tumbuh pesat di Indonesia.

Dalam sektor tenaga kerja Indonesia perlu meningkatkan kualifikasi pekerja, meningkatkan mutu pendidikan serta pemerataannya dan memberikan kesempatan yang sama kepada masyarakat. Sektor infrastruktur perlu adanya perbaikan infrastruktur fisik melalui pembangunan atau perbaikan infrastruktur seperti transportasi, telekomunikasi, jalan tol, pelabuhan, dan restrukturisasi industri. Selain itu, perlu adanya sosialisasi kepada masyarakat luas mengenai adanya Masyarakat Ekonomi ASEAN 2015 sehingga masyarakat memiliki kesadaran yang diharapkan mampu menumbuhkan rasa percaya diri dan kesiapannya ketika era Masyarakat Ekonomi ASEAN 2015 datang. (ASEAN, 2015)

\section{Tantangan MEA Bagi Masyarakat Indonesia}

Terhitung sejak 2003-2013, Penguasaan lahan oleh korporasi (dengan luas 5.000$30.000 \mathrm{Ha}$ ) mengalami pertumbuhan sebesar $24,57 \%$. Hal ini berakibat makin hilangnya akses petani terhadap lahannya (luas lahan 05000) sebanyak 5.177.195. dalam pemberlakuan MEA, ada dua dampak yang signifikan terhadap perkembangan perekonomian Negara. Yakni dampak negative dan dampak positif, keduanya tak bisa terelakan ketika MEA menjadi trending topic perekonomian di Indonesia.

Ketika MEA diberlakukan, maka para petani akan semakin termarginalkan karena kalah bersaing dengan korporasi besar. Tak pelak, angka kemiskinan kaum tani bahkan jumlah pengangguran pun semakin meningkat.( Rahmi Hertanti, 2014) Belum lagi imbas 
persaingan produk lokal dan impor. Dengan modal yang jauh lebih besar, dan penguasaan teknologi canggih plus keberpihakan negara, maka negara besar dapat memproduksi barang jauh lebih banyak, yang konsekuensinya dapat menghasilkan harga jual lebih rendah. Sementara masyarakat pada umumnya memilih membeli produk yang lebih murah meski impor, sehingga lambat-laun pengusaha lokal pun akan banyak yang gulung tikar karena kalah saing.

Dampak yang signifikan ketika MEA diberlakukan di Indonesia adalah jika korporasi asing dapat masuk menguasai sektor-sektor vital negara karena kekuatan modal yang besar, maka barang-barang kepemilikan umum seperti minyak bumi, gas bumi, dan barang tambang lain, serta sumber mata air dan hutan akan menjadi milik mereka. Rakyat akan kehilangan haknya, sedangkan pemerintah tidak bisa mengintervensi. Peran negara sebagai pelayan rakyat semakin tereduksi, hanya berfungsi sebagai regulator saja.

Akhirnya, korporasi asing dapat menyetir penguasa. Dengan mempengaruhi perpolitikan suatu negara untuk menghasilkan kebijakan yang menguntungkan perusahaan serta negara asalnya, walaupun itu harus mengorbankan jutaan rakyat lokal.

Dampak positif yang akan digagas dalam MEA adalah untuk memajukan perekonomian nasional dan membawa dampak positif pada kesejahteraan masyarakat. Beberapa alasan yang diutarakan: (1) Indonesia sudah siap bersaing dengan negara ASEAN; (2) Lapangan kerja semakin banyak; (3) Meningkatkan daya saing Indonesia di mata dunia; (4) Memaksimalkan potensi Indonesia; (5) Mempererat hubungan antar negara ASEAN.

\section{Peluang dan Tantangan indonesia dalam menghadapi MEA 2015}

Peluang Indonesia untuk dapat bersaing dalam MEA 2015 sebenarnya cukup besar, saat ini Indonesia merupakan peringkat 16 di dunia untuk besarnya skala ekonomi. Besarnya skala ekonomi juga didukung oleh proporsi penduduk usia produktif dan pertumbuhan kelas menengah yang besar. Prospek ekonomi Indonesia yang positif juga didukung oleh. Perbaikan peringkat investasi indonesia oleh lembaga peringkat dunia serta masuknya indonesia sebagai peringkat empat prospective destinations berdasarkan UNCTAD World Investment report.

Masih kuatnya fundamental perekonomian Indonesia dapat dilihat ketika banyak negara yang "tumbang" diterpa pelemahan perekonomian global, perekonomian indonesia masih dapat terjaga untuk tumbuh positif. Untuk mewujudkan peluang MEA 2015, sudah saatnya kita berbenah dan melakukan tindakan-tindakan efektif dan terarah yang didukung oleh berbagai pihak. Dari 12 sektor prioritas yang akan diimplementasikan pada MEA 2015, kita harus dapat menginventarisir sektor-sektor potensial yang menjadi unggulan.

Beberapa negara-negara ASEAN sudah mempersiapkan diri, seperti Thailand, Singapura, Malaysia dan Indonesia. Persiapan yang dilakukan oleh Indonesia pun masih sekitar $84 \%$ dan ini masih terus bertambah. kemajuan Indonesia harus perlu dipertajam agar bisa mengambil manfaat terbesar dari terbentuknya MEA. Tingkat pelaksanaan MEA masih seusai rencana. masyarakat Indonesia telah mempersiapkan diri melalui pembentukan MEA yang melibatkan pemerintah dan dunia usaha. Mantan Menteri Luar Negeri, Marty Natalegawa mengungkapkan, "pemerintah terus mempertajam pilar pembentukan Komite Ekonomi ASEAN 2015, antara lain di bidang politik dan keamanan, ekonomi dan budaya". 
Akan tetapi saingan berat Indonesia datang dari Thailand, Singapura dan Malaysia. Karena ketiga negara ini pesaing terberat dalam bidang ansuransi. Seperti yang di katakan Presiden Direktur PT JLT Arman Juffry, "semua kalangan harus siap menghadapi MEA pada 2015 termasuk kesiapan yang datang dari industri asuransi. Setidaknya akan ada tiga negara yang menjadi pesaing berat bagi Indonesia."

Selain itu dikarenakan, negara-negara seperti Singapura, Malaysia, dan Indonesia akan berkembang sebagai pusat-pusat bisnis regional. Adapun negara-negara seperti Vietnam, Laos, dan Myanmar diatur untuk menjadi pusat manufaktur. Sehingga perubahan yang terjadi di ASEAN tersebut dapat menciptakan efisiensi. Selain itu, mereka juga menyadari penghematan biaya untuk mengembangkan manfaat yang kompetitif serta perkembangan ekonomi yang merata, menurunnya tingkat kemiskinan dan perbedaan social ekonomi di kawasan ASEAN.( Afandi, 2011)

Dapat dikatakan bahwa Indonesia masih belum sepenuhnya siap dalammenghadapi MEA, dikarenakan factor infrasruktur yang masih perlu dibenahi dan perlunya sosialisasi kepada pengusaha (kecil, menengah dan besar), pekerja serta masyrakat. Akan tetapi pemerintah akan terus mendorong agar usaha mikro, kecil dan menengah (UMKM) (Tambunan, 2013) untuk dapat bersaing dalam kancah Masyarakat Ekonomi ASEAN (MEA). Namun untuk mencapai integrasi ekonomi kawasan diperlukan kerja keras baik di internal masing-masing negara anggota maupun di tingkat kawasan dalam melaksanakan komitmen bersama. Keterlibatan semua pihak di seluruh negara anggota ASEAN mutlak diperlukan agar upaya mewujudkan ASEAN sebagai kawasan yang kompetitif bagi kegiatan investasi dan perdagangann bebas dapat memberikan manfaat bagi seluruh negara anggota ASEAN.

\section{Optimalisasi Peluang Ahli Ekonomi Syariah dalam Menghadapi MEA}

Salah satu persoalan yang kini dihadapi industri keuangan syariah di Indonesia adalah ketersedian SDM berkualitas. perkembangan industri keuangan dan perbankan syariah mendorong meningkatnya kebutuhan SDM berkualitas. BI (Bank Indonesia) pernah menyatakan untuk mengejar pangsa pasar perbankan syariah menjadi lima persen, BI kekurangan tenaga kerja sekitar 40 ribu. (Muhammad, 2014)Persoalan kedua adalah kurangnya pemahaman masyarakat terhadap sistem keuangan dan bisnis syariah. Hal tersebut terlihat dari belum banyaknya masyarakat yang mengakses layanan perbankan syariah dibandingkan layanan perbankan konvensional.

Persoalan SDM di Indonesia sudah sedikit dapat diatasi dengan munculnya ahli ekonomi syariah dari berbegai perguruan tinggi Islam dapat menjadi solusi untuk mengentaskan kekurangan ahli ekonomi Islam dewasa ini. beberapa lembaga pendidikan dan pelatihan ekonomi Islam di Indonesia antara lain; Tazkia Institute, Shariah Economic and Banking Institute (SEBI), Pusat Pelatihan dan Pengembangan Sumber Daya Mandiri (PPSDM), Muamalat Institute, Karim Bussiness Consulting, dan Divisi Perbankan Syarieeah Institute Bankir Indonesia (IBI). Pada tataran pendidikan formal terdapat Program Studi Ekonomi Islam yaitu UIN MALIKI Malang, Fakultas Ilmu Agama Islam Universitas Islam Indonesia, STAIN Jember, UINSA Surabaya, SBI institute, SEBI, STIS Yogyakarta, Jurusan Ekonomi Islam STAIN Surakarta, UIN Syarif Hidayatullah Ciputat, UIN Yogyakarta, IAIN Medan, dan Fakultas Ekonomi UNAIR, STEI Tazkia, dan Jurusan Timur Tengah dan Islam UI, FAI Universita Muhammadiyah Tangerang serta upaya lain dari beberapa universitas Islam lain yang cukup banyak. 
Perkembangan praktik ekonomi Islam dalam berbagai aspeknya yang begitu pesat, membutuhkan supply SDM yang unggul dalam menjaga dan meneruskan eksistensi ekonomi Islam di dunia. Dukungan pemerintah yang semakin baik dan akomodatif terhadap perkembangan praktik ekonomi Islam, terutama lahirnya UU Perbankan Syariah dan UU Surat Berharga Syariah Negara pada tahun 2008 lalu memberikan harapan baru yang lebih cerah tentang masa depan praktik ekonomi Islam di Indonesia. Oleh karena itu, ketersediaan SDM unggul yang mendukung pengembangan dan perluasan praktik ekonomi Islam di Indonesia. khususnya, di ASEAN pada umumnya merupakan suatu keniscayaan.

Dalam rangka itu, telah banyak institusi pendidikan yang berlomba mempersiapkan SDM sesuai dengan kebutuhan industri dan bisnis yang merupakan implementasi sistem ekonomi Islam. Dengan demikian, inshaAllah masa depan ahli ekonomi Islam Indonesia ke depan semakin prospektif berkat dukungan semakin luasnya aspek praktik ekonomi Islam di negara-negara di ASEAN.

Perkembangan dan Prospek Perbankan Syariah Indonesia: Tantangan Dalam Mengimplementasikan MEA 2015.

Sebagian pihak menkhawatirkan hadirnya kesepakatan Masyarakat Ekonomi Asean (MEA) 2015 adalah sebuah ancaman. dikarenakan pasar potensial domestik akan diambil oleh pesaing dari negara lain. Kekhawatiran tersebut tidak beralasan jika memang kita mampu menunjukkan daya saing (competitiveness) yang sehat. Pertanyaanya adalah apakah industri perbankan syariah Indonesia siap menghadapi MEA 2015? Apalagi sekarang adanya isu arus inverstasi modal dari luar negeri yang menyababkan maslah kedaulatan Negara yang harus didikapi dengan bijak.

Bank syariah terbesar di Indonesia saat ini baru mampu membukukan aset sekitar US \$ 5,4 miliar, sehingga belum ada yang masuk ke dalam jajaran 25 bank syariah dengan aset terbesar di dunia. Sementara tiga bank syariah Malaysia mampu masuk ke dalam daftar tersebut. Hal ini menunjukkan bahwa skala ekonomi bank syariah Indonesia masih kalah saing dengan bank syariah Malaysia yang akan menjadi kompetitor utama. Belum tercapainya skala ekonomi tersebut membuat operasional bank syariah di Indonesia kalah efisien, terlebih sebagian besar bank syariah di Indonesia masih dalam tahap ekspansi yang membutuhkan biaya investasi infrastruktur yang cukup signifikan. Dengan menggunakan indikator rasio biaya operasional terhadap pendapatan operasional (BOPO) pada tiga bank sampel untuk masingmasing kategori terlihat bahwa bank syariah masih kalah efisien dibanding dengan bank konvensional.

Namun dari sisi net operational margin (NOM), beberapa bank syariah lebih unggul. Dari sisi profitabilitas, return on asset (ROA) bank syariah lebih kecil dari bank konvensional, namun dari sisi return on equity (ROE) lebih besar. Hal ini menunjukkan bahwa kondisi permodalan bank syariah relatif lebih kecil dibanding bank konvensional.

Kelemahan lainnya dalam menghadapi MEA 2015 adalah diferensiasi produk keuangan syariah di Indonesia yang dinilai masih kurang. Hal ini disebabkan oleh faktor bisnis model industri keuangan syariah di Indonesia, khususnya perbankan syariah, yang lebih fokus pada pemenuhan kebutuhan di sektor riil dan sangat menjaga 'maqasid syariah'. Hal ini berbeda dengan negara lain yang peranan produk-produk di sektor keuangan (pasar uang dan pasar modal) lebih dominan. 
Kendala lainnya yang perlu mendapat perhatian serius adalah upaya untuk memenuhi gap SDM dari tenaga kerja domestik agar tidak diisi oleh tenaga kerja asing. Perlu disadari bahwa salah satu butir kesepakatan dalam MEA 2015 adalah freedom of movement for skilled and talented labours. Hal ini merupakan tantangan yang serius, mengingat pusat-pusat pendidikan dan pelatihan keuangan dan perbankan syariah berada di luar negeri seperti Bahrain, Uni Emirat Arab, dan Malaysia.

Pelaku industri perbankan syariah dapat bekerjasama mendirikan 'pusat pendidikan dan pelatihan perbankan syariah' untuk mencetak tenaga ahli guna memenuhi gap tersebut daripada saling bersaing dan melakukan 'pembajakan pegawai'. IAEI tentunya dapat berperan dalam menyediakan tenaga ahli untuk mengajar di pusat pendidikan dan pelatihan tersebut. Agar lebih terarah dan tepat guna, IAEI juga dapat membantu melakukan penelitian untuk mengidentifikasi jenis-jenis keahlian yang dibutuhkan oleh industri perbankan syariah sehingga strategi 'link and match' dapat dijalankan.

\section{Peluang dan tantangan Pendidikan Entrepreneurship di Perguruan Tinggi}

Pendidikan merupakan hal yang penting bagi setiap manusia, dan saat ini telah menjadi kebutuhan pokok. Disebut demikian karena semakin banyak masyarakat yang melanjutkan pendidikan hingga tingkat universitas. Setiap universitas haruslah diiringi dengan adanya mahasiswa yang unggul, terampil, cakap, kritis, dan bersikap ilmiah terhadap peristiwa yang terjadi di sekitarnya.(Zainal Arif \& Zulfitria, 2018) dan ini menjasi peluang sekalidus tantangan menghadapi MEA.

Bagi para mahasiswa entrepreneurship perlu didorong untuk berani mengambil inisiatif dalam melakukan percobaan pilot project usaha mereka serta menyelesaikan berbagai tantangan dan permasalahan yang muncul dari usaha tersebut.

Oleh karena itu, pendidikan berwawasan kewirausahan semakin memperoleh momentum pada saat ini di berbagai belahan dunia, termasuk di tanah air. Namun sayangnya berbagai lembaga pendidikan tinggi Islam di Indonesia belum memperlihatkan political will yang kuat untuk mengarahkan orientasinya ke arah ini. Program studi atau bahkan fakultas ekonomi Islam di banyak perguruan tinggi Islam umumnya hanya menawarkan mata kuliah-mata kuliah yang banyak diadposi dari fakultas ekonomi konvensional untuk kemudian diinjeksi dengan nilai-nilai keislaman ataupun digabungkan dengan ilmu-ilmu keislaman tradisional.

Tabel 1. Penduduk Usia 15 Ke Atas yang BekerjaMenurut Pendidikan Tertinggi

\begin{tabular}{|c|c|c|c|c|c|}
\hline \multirow{2}{*}{$\begin{array}{c}\text { Pendidikan Tertinggi yang } \\
\text { Ditamatkan }\end{array}$} & \multirow{2}{*}{$\begin{array}{c}2008 \\
\text { Agustus }\end{array}$} & \multicolumn{2}{|c|}{2009} & \multicolumn{2}{|c|}{2010} \\
\hline & & Februari & Agustus & Februari & Agustus \\
\hline (1) & $(2)$ & (3) & $(4)$ & (5) & (6) \\
\hline 1. SD ke bawah & 55,33 & 55,43 & 55,21 & 55,31 & 54,51 \\
\hline 2. Sekolah Menengah Pertama & 19,04 & 19,85 & 19,39 & 20,30 & 20,63 \\
\hline 3. Sekolah Menengah Atas & 14,39 & 15,13 & 14,58 & 15,63 & 15,92 \\
\hline 4. Sekolah Menengah Kejuruan & 6,76 & 7,19 & 8,24 & 8,34 & 8,88 \\
\hline 5. Diploma I/II/III & 2,87 & 2,68 & 2,79 & 2,89 & 3,02 \\
\hline 6. Universitas & 4,15 & 4,22 & 4,66 & 4,94 & 5,25 \\
\hline Jumlah & 102,55 & 104,49 & 104,87 & 107,41 & 108,21 \\
\hline
\end{tabular}

Dapat disimpulkan dari tabel di atas bahwa tamatan universitas atau perguruan tinggi jumlahnya lebih sedikit dibandingkan tingkat SD (Sekolah Dasar) yang artinya 
bahwa mutu angkatan kerja di Indonesia hanya sebagian kecil lulusan perguruan tinggi. Dengan rendahnya kualitas angkatan kerja terindikasi dari perkiraan komposisi angkatan kerja yang sebagian besar berpendidikan hanya SD lebih banyak dibandingkan pendidikan diatasnya yaitu SMP, SMA, maupun Perguruan Tinggi. Hal ini berdampak kepada daya saing dan kompetensi dalam memperoleh kesempatan kerja baik di dalam maupun di luar negeri.

Hal ini mengisyaratkan bahwa mutu pendidikan, khususnya pendidikan kewirausahaan untuk peserta didik sangat penting. Sehubungan dengan hal tersebut, peningkatan mutu pembelajaran dan faktor-faktor lain yang mempengaruhi hasil belajar perlu dilakukan secara sistematis dan berkelanjutan.

Peluang dan tantangan Pendidikan entrepreneurship memerlukan pergeseran paradigma dalam metodologi pembelajaran. Ada beberapa kasus di mana pelatihan individu-individu berpusat pada mahasiswa dan diikuti oleh dukungan coaching dan penghubungan ke sektor swasta, sehingga membawa dampak yang terlihat jelas, terutama terkait dengan: (a) pendekatan-pendekatan praktis, (b) jumlah mahasiswa yang mempertimbangkan untuk membuka usaha di masa yang akan datang, (c) jumlah mahasiswa yang dapat menghubungkan pembelajaran mereka sekarang dan pekerjaan mereka di masa yang akan datang. (Leonardos, 2011)

Untuk mencapai hal tersebut bekal apa yang perlu diberikan kepada peserta didik agar memiliki karakter dan atau perilaku wirausaha yang tangguh, sehingga nantinya akan dapat menjadi manusia yang jika bekerja di kantor akan akan menjadi tenaga kerja yang mandiri kerja dan jika tidak bekerja di kantor akan menjadi manusia yang mampu menciptakan lapangan perkerjaan minimal bagi dirinya sendiri.

Kebijakan untuk menanggulangi masalah yang terkait dengan kewirausahaan antara lain dapat dilakukan dengan cara:

a) menanamkan pendidikan kewirausahaan ke dalam semua mata pelajaran, bahan ajar, ekstrakurikuler, dan kegiatan pengembangan diri.

b) mengembangkan kurikulum pendidikan yang memberikan muatan pendidikan kewirausahaan yang mampu meningkatkan pemahaman tentang kewirausahaan, menumbuhkan karakter dan keterampilan berwirausaha.

c) menumbuhkan budaya berwirausaha di lingkungan sekolah. Nilai-nilai yang dikembangkan dalam buku pedoman ini mengarah pada pengembangan nilainilai dari ciri-ciri seorang wirausaha. (Mulyani, 2010)

\section{KESIMPULAN}

Perkembangan praktik ekonomi Islam dalam berbagai aspeknya begitu pesat membutuhkan supply SDM yang unggul dalam menjaga dan meneruskan eksistensi ekonomi Islam di dunia. Terbukti dengan banyaknya institusi pendidikan yang berlomba mempersiapkan SDM sesuai dengan kebutuhan industri dan bisnis yang merupakan implementasi sistem ekonomi Islam. Dengan demikian, inshaAllah masa depan ahli ekonomi Islam Indonesia ke depan semakin prospektif berkat dukungan semakin luasnya aspek praktik ekonomi Islam di negara-negara di ASEAN.

Berbagai peluang dan tantangan di atas menunjukkan bahwa upaya keras dari seluruh stake holders industri keuangan syariah sangat dibutuhkan. Perlu keterpaduan 
langkah dari para praktisi, akademisi maupun asosiasi agar pengembangan menjadi lebih efektif dan efisien. agar dapat menghindari terjadinya redundancy dan suaranya menjadi lebih didengar. Untuk itu, peran IAEI (ikatan ahli ekonomi Islam) dalam mempelopori dan mendorong keterpaduan langkah untuk menjawab berbagai tantangan tersebut sangat diperlukan sehingga industri keuangan syariah nasional sema kin berkualitas, berkembang secara berkelanjutan dan mampu bersaing dalam kancah persaingan global, khususnya dalam melaksanakan MEA 2015.

\section{REFRENSI}

Afandi, Moch Masykur. 2011. Peran dan Tantangan AEC Dalam Mewujudkan Integrasi Ekonomi Kawasan. SPEKTRUM: Jurnal Ilmu Politik Hubungan Internasional, Vol. 8, No. 1, Januari.

Arif, Zainal \& Zulfitria. 2018. Membangun Kewirausahaan (Entrepreneurship) Qur'ani Di Perguruan Tinggi . Jurnal Rausyan Fikr.Vol.14. No.1

http://www.erwinnomic.com/2011/02/ekonomi-syariah-atau-ekonomiislam.html https://mridwancenter.wordpress.com_perbedaan ekonomi syari'ah dan ekonomiIslam,

Leonardos. 2009. Kewirausahaan. Teori, Praktek dan Kasus-kasus. Jakarta: Salemba Empat.

Muhammad. 2013. Bank Syariah Analisis Kekuatan, Kelemahan, Peluan dan Ancaman. Yogyakarta: Ekonisia.

Mulawarman, Aji Dedi. 2013. Masa Depan Ekonomi Islam: Dari Paradigma Menuju Metodologi. Jurnal Ekonomi, Manajemen dan Akuntansi Islam IMANENSI,Vol. 1, No. 1, September

Mulyani, 2010. PENGEMBANGAN PENDIDIKAN KEWIRAUSAHAAN, Kementrian Pendidikan Nasional Badan Penelitian dan Pengembangan Pusat Kurikulum

Nafis, Abdul wadud. 2014. Prospek ahli ekonomi Syariah dalam mengahdapi ASEAN Economic Community. Iqtishoduna Vol. 4 No. 1 April

Pitsuwan, Surin. (sekretaris jendral ASEAN). 2009. ASEAN jangan hanya libatkan pemerintah, kalangan swasta dan media masa juga perlu dilibatkan. Bangkok; Kompas Minggu.

Su'ud, Mahmud Abu. 1968. Khuthut ra'isiyyah fi al-Iqtisha`d al-Isla`miyy. Maktabat almana`r al-isla`miyyah. Kuwait .

Tambunan, Tulus T.H. 2013. Masyarakat Ekonomi ASEAN; Peluang dan tantangan bagi UKM Indonesia. Policy Paper no; 15 .

Winantyo. 2008. Masyarakat Ekonomi ASEAN di tengah Kompetisi Global. Jakarta: Elexmedia Komputindo.

Yulianti, Rahmani Timorita. 2012. Perbankan Islam di Indonesia (Studi Peraturan Perundang-undangan). Jurnal Penelitian Ilmu-ilmu Sosial FENOMENA. Vol. 01 No.2, Yogyakarta: Lembaga Penelitian UII. 